FNAL/C- $-92 / 241$

DE93 001952

\title{
SSC Collider Dipole Magnets Field Angle Data
}

M. Kuchnir, M. Bleadon, E. Schmidt, R. Bossert, J. Carson, S.W. Delchamps, S. Gourlay, R. Hanft, W. Koska. M.J. Lamm, P.O. Mazur, D. Orris, J. Ozelis, J. Strait, M. Wake

Fermi National Accelerator Laboratory

P.O. Box 500, Batavia, Illinois 60510

J. DiMarco, A. Devred, J. Kuzminski, T. Ogitsu, Y. Yu, H. Zheng

SSC Laboratory

2550 Beckleymeade Ave., Dallas, Texas 75237

DISCLAIMER

\begin{abstract}
This report was prepared as an account of work sponsored by an agency of the United States Government. Neither the United States Government nor any agency thereof, nor any of their employees, makes any warranty, express or implied, or assumes any legal liability or responsibility for the accuracy, completeness, or usefulness of any information, apparatus, product, or process disclosed, or represents that its use would not infringe privately owned rights. Reference herein to any specific commercial product, process, or service by trade name, trademark, manufacturer, or otherwise does not necessarily constitute or imply its endorsement, recommendation, or favoring by the United States Government or any agency thereof. The views and opinions of authors expressed herein do not necessarily state or reflect those of the United States Government or any agency thereof.
\end{abstract}

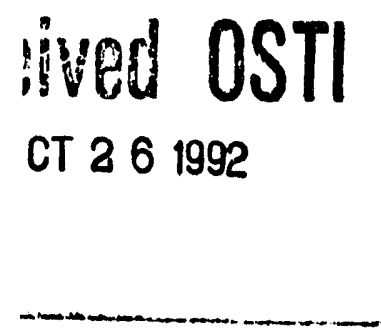

September 1992

Presented at the XVth International Conference on High Energy Accelerators, Hamburg, Germany, July 20-24, 1992 


\title{
SSC Collider Dipole Magnets Field Angle Data*
}

\author{
M. Kuchnir, M. Bleadon, E. Schmidt, R. Bossert, J. Carson, S.W. Delchamps, S. Gourlay, R. Hanft, \\ W. Koska, M.J. Lamm, P.O. Mazur, D. Orris, J. Ozelis, J. Strait, M. Wakel \\ Fermi National Accelerator Laboratory, P.O. Box 500, Batavia, IL 60510 USA
}

J. DiMarco, A. Devred, J. Kuzminski, Y. Yu§, H. Zheng

SSC Laboratory, 2550 Beckleymeade Ave., Dallas, TX 75237 USA

T. Ogitsu,

SSC Laboratory, 2550 Beckleymeade Ave., Dallas, TX 75237 USA and

KEK, National Laboratory for High Energy Physics, 1-1 Oho, Tsukuba-shi, Ibaraki-ken 305, Japan

\begin{abstract}
In the fabrication of both 40 and $50 \mathrm{~mm}$ collider dipole superconducting magnets, surveys of the direction of the magnetic field along their length have been taken. This data besides being used for certifying compliance with the specifications for the finished magnet, yields interesting information on the straightness and rigidity of the coil placement between some stages in their manufacture and testing. A discussion on the messuring equipment and procedures is given. All of the $\mathbf{4 0} \mathrm{mm}$ magnets that were built or cryostat at Fermilab have at least one of these surveys, and a summary of the data on them is presented. Most of the $50 \mathrm{~mm}$ magnets built and cold tested at Fermilab have been surveyed before and after insertion in the cryostat and before and after being cold tested. A summary of this data is also presented.
\end{abstract}

\section{Introduction}

Early in the development of full size SSC collider dipole magnet prototypes the need arose for certifying the orientation of the magnet cold mass in its cryostat. A simple instrument that measures the direction of the local magnetic field with respect to gravity was designed and built to accomplish this task[1]. The data collected with this instrument as function of position inside the beam tube (sweeps) yield more than the aveiage direction of the magnetic field which is used for the orientation task.

The plots of field direction vs. axial position are characteristic for each magnet and can be used as magnet identifying FAP (Field Angle Probe) signatures. Changes in the signature of a magnet were seldom observed in the $40 \mathrm{~mm}$ series. From thes signatures one can infer the twists in the coil if the iron magnetization is assumed uniform. The need for this assumption comes from the fact that these measurements are carried out at low fields (typically $.01 \mathrm{~T}$ ) with the magnet at room temperature and energized with currents of $10 \mathrm{~A}$ or less.

All the prototypes of the first series (with $40 \mathrm{~mm}$ diameter beam tubes) were swept with this instrument at least once if they have ever been at Fermilab. Most of them were measured before and after insertion in their cryostats. The effort involved in carrying out these measurements in the early cays and the schedule pressure restricted more extensive testing.

\footnotetext{
This work was supported by the U.S. Department of Energy. \$Permanent address: Institute of Electrical Engineering, Beijing 100080, China

ICurrent address: SSC Laborntory, USA; permanent address: KEK, Japan
}

The procedure for carrying out these measurements has evolved from taking over 12 hours to approximately 2.5 hours, mostly through automation[2] which still today includes manual displacement of the piobe from point to point ( $76.2 \mathrm{~mm}$ apart) along the beam tube. Efforts have been made to move the probe automatically [3].

For the prototypes of the second series (with $50 \mathrm{~mm}$ diameter beam tubes), this data was designated as a required part of the set of magnetic field quality characterization parameters and specifications for them were developed. Also they were swept more frequently, usually at four to six different stages in their fabrication. These stages are designated in Tubles I and II as the following:

A. before insertion in the cryostat

B. before leaving the manufacturing building (ICB)

C. after installation in its test stand at MTF (Magnet Test Facility) before cool down

D. after cold testing while still installed in the test stand

E. between test cycles at MTF

F. while in storage waiting for shipment to the SSC Laboratory.

In this paper we proceed by briefly describing the measuring system, showing a typical set of data for a typical recently measured magnet, discussing its parameterization for presentation in tabulated form and presenting tables with most of the measurements taken so far.

\section{The Measuring System}

All the data presented in this paper have been taken with the probe described in reference [1]. This probe consists of a small permanent magnet in a gimbal, on whose floating frame is mounted an electrolytic bubble level sensor. This probe is positioned inside the beam tube by means of a set of $1.83 \mathrm{~m}$ long connecting rods with distance markings every $.0254 \mathrm{~m}$.

Improvements since the description in reference [1] have been: a data acquisition system[2] that evaluates the final angle of the permanent magnet before it settles down (reducing the measuring time and static friction problems), and guides the operator through the measuring procedure; a set of stops that limits the angle range of the floating frame 
Table I

FAP Messurements Summary $40 \mathrm{~mm}$ Magnet Tests

\begin{tabular}{|c|c|c|c|c|c|c|}
\hline Magnet & Date & $\begin{array}{l}\text { Max. } \\
\text { (mrad) }\end{array}$ & $\underset{\text { (mrad) }}{\text { Min }}$ & $\begin{array}{l}\text { S. Dev } \\
\text { (mrad) }\end{array}$ & $\begin{array}{l}\text { Noise } \\
\text { (mrad) }\end{array}$ & Stage \\
\hline Doroool & 870120 & 3.0 & -7.5 & 2.72 & $0 . \alpha_{1 / 2}$ & D \\
\hline $\mathrm{DDO}^{2} 0 \mathrm{O}^{\circ} 2$ & 861112 & 6.4 & -3.9 & 2.40 & 0.94 & $B$ \\
\hline $\begin{array}{l}\text { DDo00X } \\
\text { DD000X } \\
\text { DD000X } \\
\text { DD000X }\end{array}$ & $\begin{array}{l}870413 \\
870421 \\
870513 \\
880319\end{array}$ & $\begin{array}{l}8.3 \\
8.2 \\
7.7 \\
7.4 \\
\end{array}$ & $\begin{array}{r}-9.6 \\
-9.0 \\
-10.1 \\
-8.5 \\
\end{array}$ & $\begin{array}{l}3.52 \\
3.78 \\
3.94 \\
3.48 \\
\end{array}$ & $\begin{array}{l}0.51 \\
0.73 \\
0.65 \\
0.59\end{array}$ & $\begin{array}{l}A \\
A \\
B \\
D\end{array}$ \\
\hline $\begin{array}{l}\text { DDO000Z } \\
\text { DD000Z }\end{array}$ & $\begin{array}{l}870912 \\
871003\end{array}$ & $\begin{array}{l}8.5 \\
10.3\end{array}$ & $\begin{array}{l}-7.5 \\
-9.1 \\
\end{array}$ & $\begin{array}{l}4.77 \\
6.17\end{array}$ & $\begin{array}{l}1.66 \\
0.61\end{array}$ & $\begin{array}{l}C \\
B\end{array}$ \\
\hline $\begin{array}{l}\text { DDo010 } \\
\text { DD0010 }\end{array}$ & $\begin{array}{l}871212 \\
880602\end{array}$ & $\begin{array}{l}11.2 \\
10.4\end{array}$ & $\begin{array}{l}-8.1 \\
-8.9\end{array}$ & $\begin{array}{l}7.52 \\
3.72\end{array}$ & $\begin{array}{l}0.85 \\
0.28\end{array}$ & $\begin{array}{l}C \\
D\end{array}$ \\
\hline $\begin{array}{l}\text { DDAOTO } \\
\text { DDA010 }\end{array}$ & $\begin{array}{l}890314 \\
890408\end{array}$ & $\begin{array}{l}4.7 \\
5.3\end{array}$ & $\begin{array}{l}-6.3 \\
-6.7 \\
\end{array}$ & $\begin{array}{l}2.32 \\
2.35 \\
\end{array}$ & $\begin{array}{l}0.34 \\
0.33\end{array}$ & $\begin{array}{l}\mathrm{A} \\
\mathrm{B}\end{array}$ \\
\hline $\begin{array}{l}\text { DDOOII } \\
\text { DD0011 }\end{array}$ & $\begin{array}{l}880531 \\
880625\end{array}$ & $\begin{array}{l}8.7 \\
9.6\end{array}$ & $\begin{array}{l}-10.1 \\
-8.7 \\
\end{array}$ & $\begin{array}{l}4.12 \\
3.94 \\
\end{array}$ & $\begin{array}{l}0.79 \\
0.35\end{array}$ & $\begin{array}{l}\mathrm{A} \\
\mathrm{C}\end{array}$ \\
\hline $\begin{array}{l}\text { DDO0112 } \\
\text { DD0012 } \\
\text { DD0012 }\end{array}$ & $\begin{array}{l}8801122 \\
880203 \\
880211\end{array}$ & $\begin{array}{l}7.8 \\
9.1 \\
9.3\end{array}$ & $\begin{array}{l}-11.6 \\
-10.3 \\
-10.1\end{array}$ & $\begin{array}{l}4.13 \\
4.48 \\
4.43\end{array}$ & $\begin{array}{l}0.66 \\
0.41 \\
0.31\end{array}$ & $\begin{array}{l}\mathrm{A} \\
\mathrm{C} \\
\mathrm{C}\end{array}$ \\
\hline $\begin{array}{l}\text { DDO013 } \\
\text { DD0013 }\end{array}$ & $\begin{array}{l}8807 / 08 \\
880909\end{array}$ & $\begin{array}{l}8.2 \\
7.3 \\
\end{array}$ & $\begin{array}{r}-8.3 \\
-8.5 \\
\end{array}$ & $\begin{array}{l}2.96 \\
2.85 \\
\end{array}$ & $\begin{array}{l}0.32 \\
0.34\end{array}$ & $\begin{array}{l}\mathrm{A} \\
\mathrm{C}\end{array}$ \\
\hline $\begin{array}{l}\text { DDO014 } \\
\text { DD0014 }\end{array}$ & $\begin{array}{l}880302 \\
880527\end{array}$ & $\begin{array}{l}5.5 \\
5.2 \\
\end{array}$ & $\begin{array}{l}-10.2 \\
-7.9\end{array}$ & $\begin{array}{l}3.06 \\
2.66\end{array}$ & $\begin{array}{l}0.43 \\
1.00 \\
\end{array}$ & $\begin{array}{l}\mathrm{A} \\
\mathrm{C}\end{array}$ \\
\hline $\begin{array}{l}\text { DDO015 } \\
\text { DD0015 }\end{array}$ & $\begin{array}{l}880910 \\
880928\end{array}$ & $\begin{array}{l}4.8 \\
4.7 \\
\end{array}$ & $\begin{array}{l}-6.2 \\
-5.8 \\
\end{array}$ & $\begin{array}{l}2.79 \\
2.69\end{array}$ & $\begin{array}{l}0.27 \\
0.26\end{array}$ & $\begin{array}{c}\mathrm{A} \\
\mathrm{C}\end{array}$ \\
\hline $\begin{array}{l}\text { DDo016 } \\
\text { DD0016 }\end{array}$ & $\begin{array}{l}881230 \\
890119\end{array}$ & $\begin{array}{l}5.5 \\
4.9 \\
\end{array}$ & $\begin{array}{l}-5.2 \\
-5.3 \\
\end{array}$ & $\begin{array}{l}2.05 \\
2.09 \\
\end{array}$ & $\begin{array}{l}0.28 \\
0.36 \\
\end{array}$ & $\begin{array}{l}\mathrm{A} \\
\mathrm{C}\end{array}$ \\
\hline $\begin{array}{l}\text { DDO0117 } \\
\text { DD0017 } \\
\text { DD0017 }\end{array}$ & $\begin{array}{l}890117 \\
890203 \\
890927\end{array}$ & $\begin{array}{l}8.0 \\
7.6 \\
9.2\end{array}$ & $\begin{array}{l}-5.6 \\
-7.1 \\
-6.9\end{array}$ & $\begin{array}{l}2.05 \\
2.26 \\
2.22\end{array}$ & $\begin{array}{l}0.45 \\
0.46 \\
0.56 \\
\end{array}$ & $\begin{array}{l}\mathrm{A} \\
\mathrm{C} \\
\mathrm{D}\end{array}$ \\
\hline $\begin{array}{l}\text { DDO018 } \\
\text { DD0018 }\end{array}$ & $\begin{array}{l}890302 \\
890721\end{array}$ & $\begin{array}{l}8.3 \\
8.0\end{array}$ & $\begin{array}{r}-8.9 \\
-11.4 \\
\end{array}$ & $\begin{array}{l}2.89 \\
3.24\end{array}$ & $\begin{array}{l}0.73 \\
0.43\end{array}$ & $\begin{array}{l}\bar{A} \\
\mathrm{D}\end{array}$ \\
\hline $\begin{array}{l}\text { DD0019 } \\
\text { DD0019 } \\
\text { DD0019 }\end{array}$ & $\begin{array}{l}890812 \\
890828 \\
900209\end{array}$ & $\begin{array}{l}4.9 \\
5.2 \\
4.9\end{array}$ & $\begin{array}{l}-5.2 \\
-4.1 \\
-3.9\end{array}$ & $\begin{array}{l}2.16 \\
2.01 \\
1.84 \\
\end{array}$ & $\begin{array}{l}0.56 \\
0.37 \\
0.35\end{array}$ & $\begin{array}{l}\text { A } \\
\text { C } \\
\text { D }\end{array}$ \\
\hline $\begin{array}{l}\mathrm{DDO0026} \\
\mathrm{DD} 0026\end{array}$ & $\begin{array}{l}890911 \\
891010\end{array}$ & $\begin{array}{l}4.7 \\
4.7\end{array}$ & $\begin{array}{l}-7.0 \\
-6.5\end{array}$ & $\begin{array}{l}2.41 \\
2.43\end{array}$ & $\begin{array}{l}0.27 \\
0.38\end{array}$ & $\begin{array}{l}\mathrm{A} \\
\mathrm{C}\end{array}$ \\
\hline $\begin{array}{l}\text { DDO027 } \\
\text { DDO027 } \\
\text { DD0027 }\end{array}$ & $\begin{array}{l}9002043 \\
900311 \\
701011\end{array}$ & $\begin{array}{l}5.3 \\
5.9 \\
5.5 \\
\end{array}$ & $\begin{array}{l}-6.7 \\
-7.1 \\
-6.3 \\
\end{array}$ & $\begin{array}{l}2.43 \\
2.51 \\
2.18\end{array}$ & $\begin{array}{l}0.7 / 2 \\
0.29 \\
0.31\end{array}$ & $\begin{array}{l}\text { A } \\
\text { C } \\
\text { D }\end{array}$ \\
\hline $\begin{array}{l}\text { DDO028 } \\
\text { DD0028 } \\
\text { DD0028 } \\
\text { DD0028 }\end{array}$ & $\begin{array}{l}900423 \\
900730 \\
900928 \\
901205\end{array}$ & $\begin{array}{l}6.2 \\
6.8 \\
7.1 \\
6.0\end{array}$ & $\begin{array}{l}-8.1 \\
-7.7 \\
-6.5 \\
-6.3\end{array}$ & $\begin{array}{l}3.14 \\
3.33 \\
3.22 \\
2.87 \\
\end{array}$ & $\begin{array}{l}0.34 \\
0.59 \\
0.34 \\
0.45\end{array}$ & $\begin{array}{l}\mathrm{A} \\
\mathrm{B} \\
\mathrm{C} \\
\mathrm{D}\end{array}$ \\
\hline $\begin{array}{l}\mathrm{DC} .02022 \\
\mathrm{DCO} 202\end{array}$ & $\begin{array}{l}901102 \\
901210\end{array}$ & $\begin{array}{l}8.3 \\
7.1 \\
\end{array}$ & $\begin{array}{l}-4.1 \\
-4.1\end{array}$ & $\begin{array}{l}2.16 \\
2.26\end{array}$ & $\begin{array}{l}0.34 \\
0.29\end{array}$ & $\begin{array}{l}\mathrm{A} \\
\mathrm{B}\end{array}$ \\
\hline DeO301 & 901004 & 3.6 & -4.8 & 1.21 & 0.39 & $\mathrm{~B}$ \\
\hline $\begin{array}{l}\text { DC0304 } \\
\text { DC0304 } \\
\text { DC0304 }\end{array}$ & $\begin{array}{l}910221 \\
910311 \\
910424\end{array}$ & $\begin{array}{l}4.3 \\
3.3 \\
2.4 \\
\end{array}$ & $\begin{array}{l}-3.8 \\
-3.4 \\
-3.3 \\
\end{array}$ & $\begin{array}{l}1.35 \\
1.11 \\
1.08\end{array}$ & $\begin{array}{l}0.37 \\
0.44 \\
0.29\end{array}$ & $\begin{array}{l}\text { B } \\
\text { C } \\
\text { D }\end{array}$ \\
\hline $\begin{array}{l}\text { DC0306 } \\
\text { DC0306 } \\
\text { DC0306 }\end{array}$ & $\begin{array}{l}910410 \\
910423 \\
910627\end{array}$ & $\begin{array}{l}4.3 \\
5.1 \\
4.3\end{array}$ & $\begin{array}{l}-4.1 \\
-3.6 \\
-4.2\end{array}$ & $\begin{array}{l}1.40 \\
1.66 \\
1.65\end{array}$ & $\begin{array}{l}0.43 \\
0.49 \\
1.33\end{array}$ & $\begin{array}{l}\text { B } \\
\text { C } \\
\text { D }\end{array}$ \\
\hline
\end{tabular}

and has since kept the calibration curve of the device from changing in normal use.

Other instruments[4-6] have since been desscribed in the literature, nevertheless, a second system like this one has been manufactured to be sent to the SSC Laboratory.

Two of the characteristics of this system that reflect in the way the data is acquired are:

a) the rotational freedom of the floating frame of the gimbal is slightly compromised by the torque from the wires connecting the level sensor to the external case of the probe which therefore has to be kept aligned by the operator:
Table II

FAP Measurements Summary $50 \mathrm{~mm}$ Magnet Teats

\begin{tabular}{lcccccc} 
Magnets & Date & $\begin{array}{c}\text { Max. } \\
\text { (mrad) }\end{array}$ & $\begin{array}{c}\text { Min. } \\
\text { (mrad) }\end{array}$ & $\begin{array}{c}\text { S.Dev. } \\
\text { (mrad) }\end{array}$ & $\begin{array}{c}\text { Noise } \\
\text { (mrad) }\end{array}$ & Suge \\
\hline DCA311 & 911031 & 5.5 & -7.5 & 2.82 & 0.38 & B \\
DCA311 & 911104 & 5.0 & -8.5 & 2.58 & 0.59 & C \\
DCA311 & 911206 & 3.5 & -6.4 & 1.89 & 1.03 & D \\
\hline DCA312 & 911016 & 4.8 & -4.7 & 2.61 & 0.37 & A \\
DCA312 & 911112 & 5.6 & -4.2 & 2.25 & 0.47 & B \\
DCA312 & 911124 & 5.5 & -4.0 & 1.88 & 0.44 & C \\
DCA312 & 911220 & 2.4 & -3.0 & 1.12 & 0.42 & D \\
\hline DCA313 & 911101 & 4.1 & -3.0 & 1.42 & 0.50 & A \\
DCA313 & 911212 & 4.9 & -3.9 & 1.68 & 0.72 & B \\
DCA313 & 911219 & 4.8 & -3.6 & 1.68 & 0.37 & C \\
DCA313 & 920116 & 5.2 & -2.7 & 1.70 & 0.46 & D \\
\hline DCA314 & 911114 & 5.7 & -6.2 & 3.17 & 0.37 & A \\
DCA314 & 920107 & 4.8 & -3.6 & 2.04 & 0.42 & B \\
DCA314 & 920115 & 4.5 & -3.8 & 2.10 & 0.38 & C \\
DCA314 & 920207 & 4.2 & -3.4 & 1.62 & 0.83 & D \\
\hline DCA315 & 911126 & 7.5 & -3.6 & 2.31 & 0.25 & A \\
DCA315 & 920123 & 6.7 & -3.3 & 1.57 & 0.61 & B \\
DCA315 & 920128 & 5.3 & -2.7 & 1.30 & 0.43 & C \\
DCA315 & 920221 & 3.7 & -2.3 & 1.09 & 0.83 & D \\
\hline DCA316 & 911217 & 4.6 & -3.5 & 1.92 & 0.41 & A \\
DCA316 & 920208 & 3.6 & -3.9 & 1.60 & 0.31 & B \\
DCA316 & 920214 & 3.5 & -4.3 & 1.68 & 0.84 & C \\
DCA316 & 911220 & 2.4 & -3.0 & 1.12 & 0.84 & D \\
\hline DCA317 & 920210 & 3.8 & -2.9 & 1.79 & 0.27 & A \\
DCA317 & 920309 & 4.6 & -3.1 & 1.91 & 0.49 & B \\
DCA317 & 920325 & 4.2 & -3.3 & 1.92 & 0.49 & C \\
DCA317 & 920403 & 3.7 & -3.0 & 1.45 & 0.67 & E \\
DCA317 & 920423 & 3.6 & -3.2 & 1.50 & 0.40 & D \\
\hline DCA318 & 920225 & 3.0 & -2.7 & 1.23 & 0.42 & A \\
DCA318 & 920317 & 3.5 & -2.5 & 1.18 & 0.45 & B \\
DCA318 & 920413 & 4.1 & -2.0 & 1.14 & 0.48 & C \\
DCA318 & 920415 & 3.9 & -2.1 & 1.11 & 0.48 & C \\
DCA318 & 920512 & 3.2 & -2.1 & 1.11 & 0.54 & D \\
\hline DCA319 & 920125 & 2.8 & -3.7 & 1.47 & 0.45 & A \\
DCA319 & 920224 & 4.1 & -3.1 & 1.44 & 0.50 & B \\
DCA319 & 920227 & 3.0 & -3.4 & 1.29 & 0.36 & C \\
DCA319 & 920320 & 2.6 & -2.5 & 0.96 & 0.95 & D \\
DCA319 & 920330 & 4.7 & -2.7 & 1.06 & 0.52 & F \\
\hline
\end{tabular}

b) the need for accurate zero determination; although the probe is frequently calibrated in a separate electromagnet that can be tilted with respect to gravity, the zero is most reliably determined by taking a pair of sweeps of data with the probe pointing to the opposite ends of the magnet.

The symmetry of these two sweeps results from the magnet FAP signature and its lack reflects the noise in the data as well as the care of the operator in keeping the external case aligned and in sampling the same spots on both sweeps. The fact that this sysuem requires a specific polarity in the magnet prevents it from distinguishing contribution from the iron yoke magnetization inhomogeneities.

\section{Data and Tabulation}

Figure 1 shows the pair of sweeps of magnet DCA315 done on Jan. 28, 1992 (a date coded as 920128). By subtracting one from the other and dividing by 2 , we get the FAP signature shown in Figure 2 as an average of the two sweeps compensated for the zero offset of the instrument. The average angle just reflects the installation 


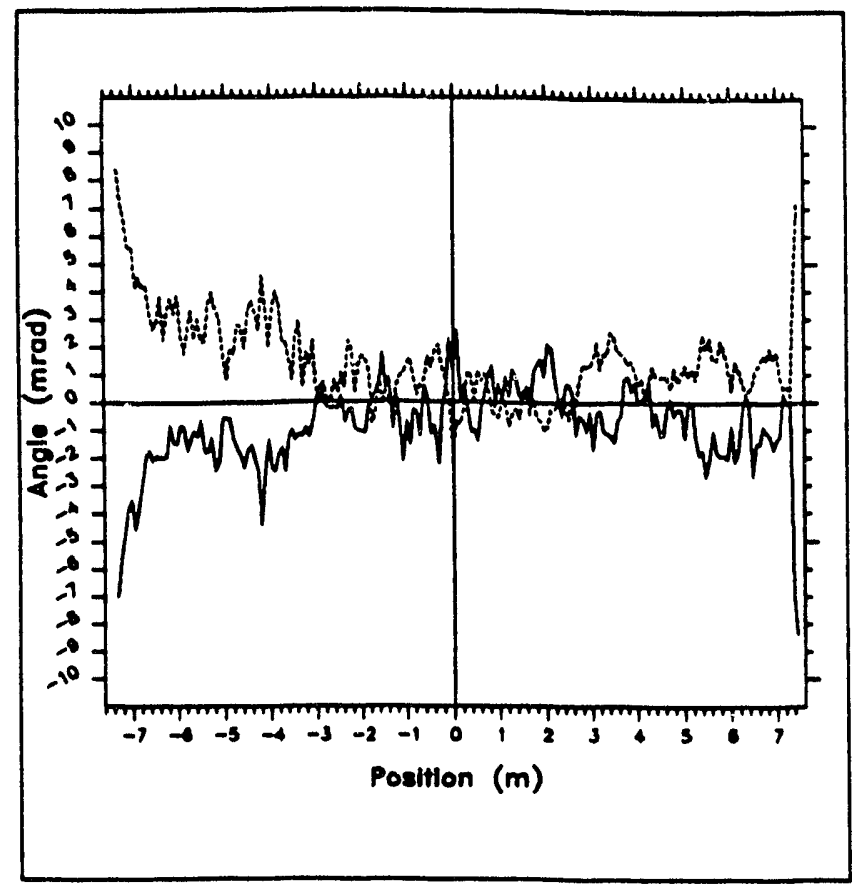

Figure 1. Pair of sweeps 920128 of Magnet DCA315 before cooldown at MTF. Solid line: probe pointing towards retum, dashed line: probe pointing cowards leads

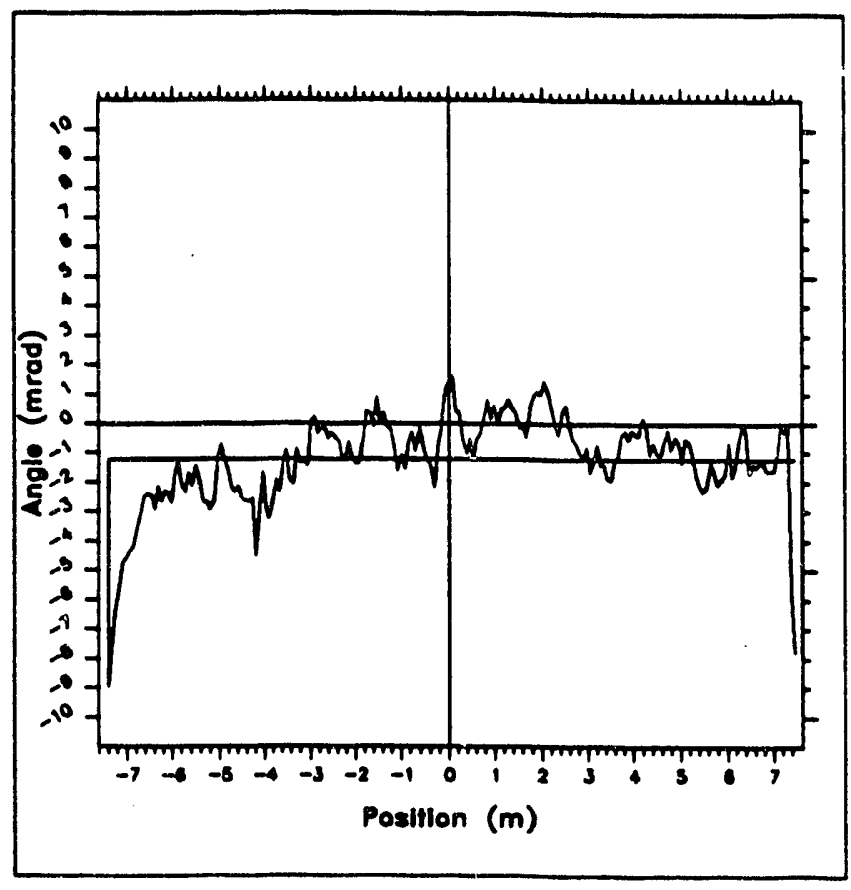

Figure 2. FAP signature at magnet DCA315 from pair of sweeps 920128 aijgnment error and is not a characteristic of the magnet.

Here this data is summarized by presenting the minimum and the maximum angles relative to the average along with the standard deviation of the FAP signature. A 4th parameter that provides an estimate of the uncertainty or lack of symmetry between the two sweeps is the standard deviation of the "background signature" obtained by adding the two sweeps and dividing by 2 . This parameter is labeled noise.

In Tables I and II we present these summarizing parameters for the $40 \mathrm{~mm}$ and $50 \mathrm{~mm}$ magnets respectively. For the $40 \mathrm{~mm}$ magnets a complete set of data has been compiled in an internal report by three of the authors[7]. The first column is the magnet label and the 2 nd column is the coded date of the measurement. They are followed by the parameters described above and a letter describing the manufacturing/testing stage of the magnet as referred in the introduction.

The specifications for these magnets regarding the field angle have been changing recently and therefore could not be included here.

\section{Acknowledgments}

We thank Dean Sorensen and Todd Nebel for managing the data acquisition and Ann Desportes for implementing the data analyzing software.

\section{References}

[1] M. Kuchnir and Ed. E. Schmidt, "Measurements of Magnetic Field Alignment", IEEE Trans. Mag., Vol.24, p. 950 (1988).

[2] M. Bleadon, Ed. Schmidt and M. Kuchnir, "Vertical Field Angle Probe Data Acquisition and Software Guide", Fermilab MTF document January 4, 1990.

[3̈] W.N. Boroski, T.H. Nicol, S.V. Pidcoe, R.A. Zink, "Self Propelled In-tube Shuttle and Control System for Automated Measurements of Magnetic Field Alignement", Supercollider 2, edited by M. McAshan, p. 381, Plenum Press, N.Y. (1990).

[4] H. Preissner, R. Bouchard, P. Luthke, A. Makulski, R. Meinke and K. Nesteruk "A New Device for Production Measurements of Field Integral and Field Direction of SC Dipols Magnets", Supercollider 2, edited by M. McAshan, p. 357, Plenum Press, N.Y. (1990).

[5] G.W. Albert, S.V. Pidcoe, S.D Peck and R.E. Bailey, "Collider Dipole Magnet Field Angle Measurement", IEEE Trans. Mag. Vol. 27, p. 2012 (1991).

[6] Branko Berkes, "Precision Magnetic Field Inclinometer", (Berkeley, April 20, 1988)

[7] J. DiMarco, M. Kuchnir, Y. Yu, "Summary of Field Angle Probe Measurements on 4-cm-Aperture $17 \mathrm{~m}$ Long Dipole Magnets", Fermilab document TS-SSC 91-206 or SSC document MD-TA-203 October 16, 1991 

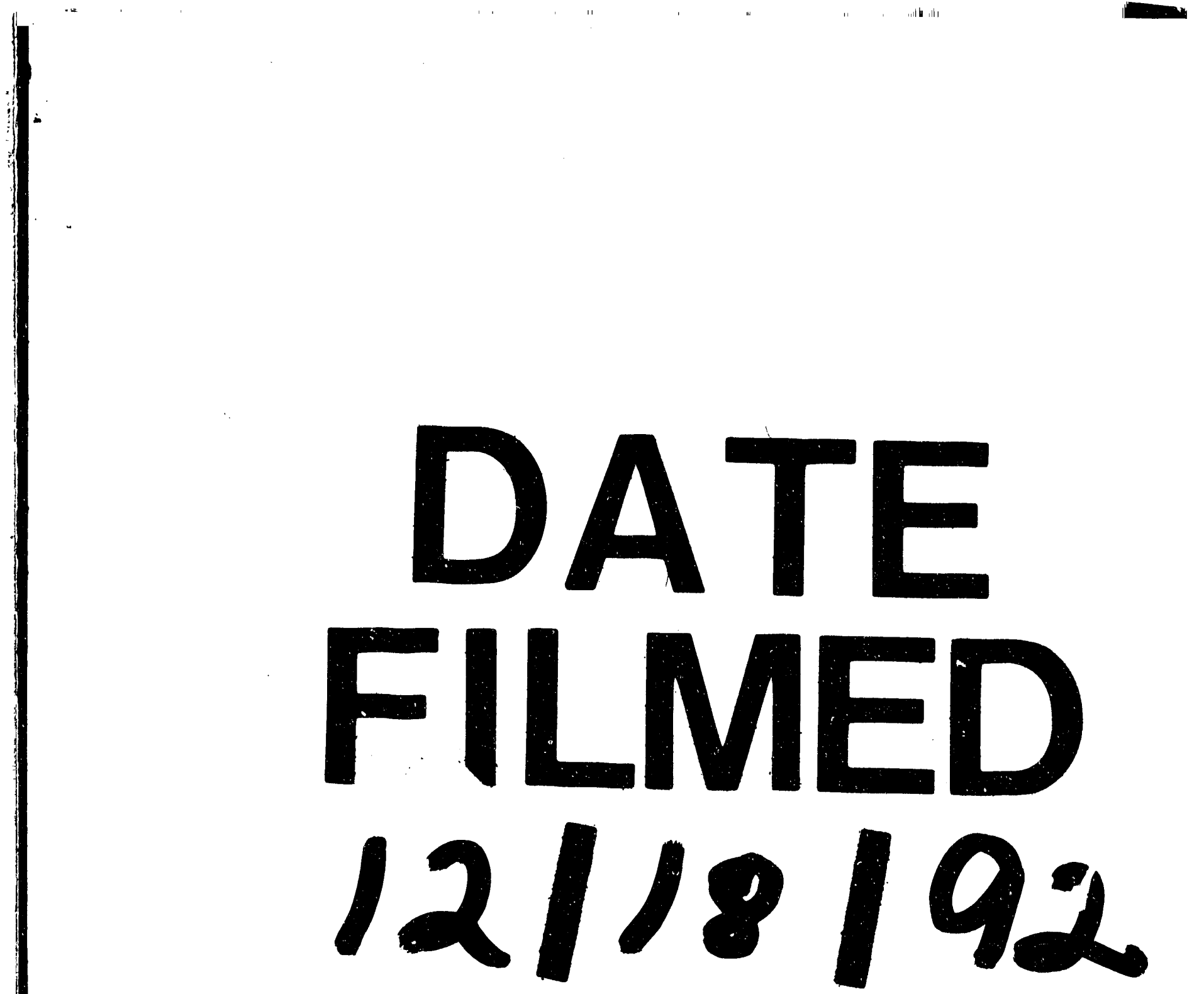
